\title{
DEVELOPING SCREENCAST O MATIC AS MEDIA OF WRITING DESCRIPTIVE TEXT FOR GRADE EIGHTH STUDENTS \\ IN JUNIOR HIGH SCHOOL
}

\author{
*Sri Suci Batubara \\ **Nora Ronita Dewi \\ **Farida Hanim Saragih
}

\begin{abstract}
This study aims to design Screencast O Matic as media of writing descriptive text for grade eighth students in Junior High School. The research was conducted by Research and Development ( $\mathrm{R} \& \mathrm{D})$ design through six stages; gathering information and data, analyzing the data, designing new writing media, validating to experts, revising writing media, and final product. The subject of this research was grade eighth students at SMP Negeri 27 Medan. The instruments used for collecting the data were interview and questionnaire. The data were gathered by administering interview to the English teacher and distributing questionnaire to 30 respondents to get the students' needs in learning descriptive text. The writing media have been validated by two experts, English teacher and English lecturer. The average score from English teacher and English lecturer was 90,4\% so it was categorized as Very Good. It means the developing Screencast O Matic as media of writing descriptive text is appropriate for grade eighth students in Junior High School.
\end{abstract}

Keywords: Research and Development $(R \& D)$, Writing media, Descriptive text, Screencast O Matic

\footnotetext{
*Graduate Status

**Lecturer Status
} 


\section{INTRODUCTION}

\section{Background of the Study}

Writing is a productive skill, students are supposed to be able to express their ideas, feelings or thoughts in written form. Martin (1992) elaborates that writing is viewed as a product of teaching and learning also made through a number of phases to follow in. Writing is considered as one of difficult skill, many people cannot write well. Feez (2002: 7) also asserts that the students often feel confuse and stuck with a blank paper for a long time to find idea to write. It also happens in Junior High School students. To enable students to get ideas, the teacher should give an innovational media to helping students develop their ideas creatively. Media divided into three parts; audio, visual, and audiovisual. Arsyad (2013: 142) defines that using audiovisual media in mastery learning is supported.

Based on the syllabus Curriculum 13 that is used by SMP Negeri 27 Medan, Students are demanded to master some genres in writing, they are descriptive, recount, and narrative. One of the genres that taught by the teacher in grade eighth is descriptive text. Saragih (2014: 44) explains that descriptive text is to describe or make pictures of natural or social phenomenon. Specifically the phenomenon may refer to persons, things or matters and places, which are either concrete or abstract.

Based on the preliminary observation of grade VIII of SMP Negeri 27 Medan about the students' writing especially in descriptive text by interviewing the English teacher, the teacher told that students have difficulties 
in arranging sentence to sentence to make a complete written text of descriptive text. She also told that students cannot clearly understand about how to write descriptive text well. In teaching learning process, the teacher also found some problems. Students felt bored during teaching learning process because of the teacher's method and media were not interested for them. The researcher found that teacher used printed picture to be the media of learning descriptive text which is old-fashioned without any other media that support the teaching learning process. Another problem is the lack of vocabulary of students; it made them difficult to write because they did not know what the suitable word to describe the thing is; it makes them hopeless to write and stuck with a blank of paper.

Based on the problems above, the writer thinks that it is important to find ways to solve the problem. One of ways to solve the problem is by using appropriate media in teaching writing. The teacher only used visual media to teaching writing so the writer thinks to develop the media into audiovisual media. Arsyad (2013) explains that audiovisual media is the combination of two kinds of media which are audio media and visual media. It can be useful to make students excited in following the teaching learning process. Unfortunately, some of the teacher did not implement the media in the class well; where the media was not interested yet.

One of the useful tools to teaching descriptive text is Screencast O Matic. It is the tool or application to record a video of any instructional activity performed on the computer screen and expands many multimedia elements 
such as music, audio, sound effect and graphics along with the text. As stated in Kholifah (2016) she was developed the learning video media based on Swishmax and Screencast O Matic through contextual approach. After the implementation of the development of learning media, the students got the best score than the students who received the conventional learning. So the development of learning media based on Screencast O Matic is a solution for solving problems in learning English. The writer intended to develop a media for teaching writing to the eighth grade students of Junior High School. The developed media hopefully can be contributed to help the teaching and learning process of writing in order to improve and develop the students' writing ability for the students need in the future.

\section{REVIEW OF LITERATURE}

Media is useful tools that help people to obtain information in easy way. Media also has advantage in teaching and learning process. National Education Association (as cited in Arsyad, 2013: 4) provides the definition of media as a forms of communication, both printed and audiovisual equipment, thus, the media can be manipulated, seen, heard, or read. Media is one of learning resources that can help student to understand the material. Rusman (2013: 160) states that learning media is one of the components of teaching learning process that has important role in stimulate students to learn. Kariman (1991:47-48) explains that there are sorts of media that can be used in language teaching. In general, they can be classified into three groups, namely: Audio 
media, Visual media, and Audio visual media. Audio Visual Media is the combination between audio and visual media. Screencast O Matic is basically a simple application for video recording from Java-based application that is used to create screencasts on operation Windows system, Mac, and Linux. Arthur (1999) claims that video can give students a real visualization to the object.

In developing media, it needs to do analysis based on needs analysis by Hutchinson and Waters (1986). They propose two basic needs of students; target needs and learning needs. Target needs define what the learners need to do in the target situation and learning needs are the knowledge and abilities that learners will require in order to be able to perform to the required degree of competence in the target situation.

The specific skill was focused on writing of descriptive text, writing is an activity that organizes idea in right words and presents those on a piece of paper. Descriptive text is the text that describe something the writer want to describe or illustrate so the reader can visualize it. Pardiyono (2007:34) explains that description is a type of written text which has the specific function to give description about an object (human or non human) and it aims is to give clearly description of the object to the reader.

\section{Relevant Studies}

The study by Anggi and Theresia (2014) "The Use of Cartoon Video as a Media to Teach Descriptive Writing Text to The Eighth Graders of Junior High School" This research is success, the researchers did three activities in observing the class. Pre-viewing activity, viewing activity, and post-activity. It 
is proved that video can help students in writing especially in descriptive text and also students were enthusiastic to watch video in learning.

Another study was "Developing Media to Teach Writing Skill for EFL Learners at Indonesia" by Dewi and Hari (2016). The objective of this research was intended to develop appropriate writing electronic media for the Tenth Grade Students' of Vocational Senior High Schools and English teachers. This study produce an electronic media for writing successfully, the name of the product is Interactive English Learning (IEL) in the form of a compact disc (CD). This media was developed based on Latief that was begun with the need analysis of the students and teachers.

Then, Siti Kholifah (2016) the title of the study is The Development of Learning Video Media Based on Swishmax and Screencast O-Matic Softwares through Contextual Approach. She is using ADDIE development model which consisted of five stages (Analysis, Design, Development, Implementation, and Evaluation). The development of media is successful and the analysis is clear, but the study is not including what skill this study wants to improve with the media.

The last study was done by Putra Sudharma (2017). It was "The Effect of Screencast-O-Matic on Students' Speaking Ability of Descriptive Text". The result is successful. Teaching speaking of descriptive text using screencast o matic can increase student's motivation in speaking skill. The students are more enthusiastic and interesting because screencast o matic is very effective to increase their speaking ability. 


\title{
RESEARCH METHODOLOGY
}

\author{
Research Design
}

This study was applied Research and Development (R \& D) research method. It was adapted from $\mathrm{R} \& \mathrm{D}$ research method proposed by Borg and Gall. Borg and Gall (2003:569) stated that the educational R \& D is industrybased development model in which findings of research are used to design new products and a procedure, which is systematically field-tested, evaluated, and refined until they meet specified criteria of effectiveness, quality or similar standard. One of the most widely used models of educational research and development was the system approach model designed by Borg and Gall (2003: 571).

The subject of this study is the eighth grade students of SMP Negeri 27 Medan. There are eight classes of grade eighth in this school and every class consists of 30-38 students.

The data were collected by interviewing the teacher and administering questionnaires to students of SMP Negeri 27 Medan.

\section{Technique of Analyzing Data}

The data was obtained from the interview firstly collected and analyzed. These data were needed to evaluate the writing media and assess the students' needs in learning writing especially in descriptive text. The data was divided into two forms of data analysis, qualitative data analysis and quantitative data analysis. The data were firstly collected, and then this research described the 
findings. The qualitative data were analyzed by showing the conclusion of the interview and the questionnaire data from students and experts changed into percentage of data.

\section{RESEARCH FINDING AND DISCUSSION}

\section{Finding}

The first is findings gotten from the needs analysis data, several considerations are concluded to develop interactive media, they are as follows:

The students were asked about students' perspective on technique of learning, kinds of media, and the material. 25 students or $83,3 \%$ said that they needed a media used by the English teacher to support them, 30 students or $100 \%$ said that they need audio-visual media to learn descriptive writing, 16 students or $53 \%$ said that they need the material presented and explained clearly, and 19 students or $63 \%$ said that they need to introduce first the vocabulary that is related to the text they wanted to write in order to help them in writing activity.

The students were asked about the students' understanding, difficulties, and suitability on learning descriptive text. There were 17 students or $57 \%$ of them still having less understand about descriptive text, 20 students or $67 \%$ agreed that all of the choices were the factors they hardly understood about descriptive text, 28 students or $93,3 \%$ agreed that sometimes they did not know how to express a text with our own words, and 
14 students or $47 \%$ agreed that the media used is not accordance with the topic about descriptive text.

The question were asked to know the media that the students' need in learning descriptive on writing skill. There were 18 students or $60 \%$ of them agreed that the picture and instrument put on the video, 24 students or $80 \%$ agreed that the learning media has voice recording to explain, 22 students or $73,3 \%$ agreed that the learning media have the appropriate color combination with the background, and 27 students or $97 \%$ agreed that the layout of the media can motivate them in learning English.

The students were asked about Students' learning needs. There were 24 students or $80 \%$ of them preferred to learn use video, 22 students or $73 \%$ preferred to learn writing from an interesting video, and 29 students or $97 \%$ preferred to write a text consist of 100 words.

From the questions given, students like teacher use media in the learning process especially on speaking skill. Next, in planning the researcher observed the curriculum, syllabus, and media used in the school. The curriculum used in the school is Kurikulum 2013. The researcher chose descriptive text in describing things as material writing text in learning media in writing skill. There were 3 videos, they are descriptive explain, example, and exercise. In developing the media, the data from need analysis and planning became the basic. The videos as learning media has length 7 minutes, consist of a text of descriptive which has character, music and 
moving images combined and mixed together. In expert judgment done, the total mean of all of the items of expert judgment from the two experts is 4.52 or $90,4 \%$. It shows that the videos as learning media are a very good media. There is some revision of the product from the experts like voice revised and put some keyword below in the video. In producing the final product of video as learning media, the researcher saved the video of descriptive writing in the form of file software (.mp4) to able to be used in classroom. Moreover, video as learning media developed above has fulfilled all of the steps, and sentenced as a very good media by experts.

\section{CONCLUSION AND SUGGESTION}

\section{Conclusion}

After analyzing the data, the researcher draws the conclusion that the students' existing writing media is not interesting and the media that is being used by the teacher was not effective enough to make the students understand about writing descriptive text. They want to have the interesting and effective media which motivate them to learn and write descriptive text. The solution for them is by designing the new learning media. Designing Screencast O Matic follows R \& D phases of Borg and Gall (2003) which is simplified into: (1) Gathering data and information, (2) Need analysis, (3) Designing the media, (4) Validating to experts, (5) Revising, and (6) Final product. Then, the product of designing the learning media for writing skill with English material about descriptive genre for grade eighth of SMP Negeri 27 Medan has validated by 
experts. From the English teacher was $93,6 \%$ and the English lecturer was $87,2 \%$, so the result score validation of the media was $90,4 \%$ and it was categorized as very good. It means that the media were valid and appropriate to used as learning media for students in the class.

\section{Suggestion}

From the conclusion above, there are some suggestions that are proposed can help for English teacher and further researchers, they are: For the teachers, teacher should consider the students' need in choosing the learning media. Media can help teacher in explaining more about the material. For this reason, Screencast O Matic is an easy application for the beginners because it only takes a simple step to make it than others. And, other researchers, this media consist of one material; Descriptive text and one skill; Writing skill. Other researcher can enrich another English material or adding another skill in developing Screencast O Matic. 


\section{REFERENCES}

Arsyad, Azhar. 2013. Media Pembelajaran. Jakarta: PT RajaGrafindo Persada.

Alifah, Siti. 2013. Pengembangan Media Pembelajaran Berbasis Multimedia Pada Pokok Bahasan Kalor Untuk Siswa SMP kelas VII. Semarang: IKIP PGRI

Borg, Walter and Gall. 2003. Educational Research: An Introduction. Seventh Edition. New York: Longman.

C, Ismail. 2006. The Use of Video as an Audio-Visual Material in Foreign Language Teaching Classroom. The Turkish Online Journal of Educational Technology (TOJET). Vol. 5, pp. 67-72.

Liasari, Dewi R. and P, Hari. 2016 Developing Media to Teach Writing Skill for EFL Learners at Indonesia.

Ningtyas, Anggi T. P. and Kumalarini, Theresia. 2014. The Use of Cartoon Video as a Media to Teach Descriptive Writing Text to The Eighth Graders of Junior High School. E-Journal Unesa. Vol. 2 No. 1, pp. 1-6.

Pardiyono. 2007. Pasti Bisa! Teaching Genre-Based Writing. Yogyakarta: Penerbit ANDI.

Rosmawaty. 2013. Enhancing the L1 Primary Students' Achievement in Writing Paragraph by Using Pictures. International Journal of Education \& Literacy Studies, Vol. 1 No. 2, pp. 235-249.

Rusman. 2013. Belajar dan Pembelajaran Berbasis Komputer. Bandung: Penerbit Alfabeta.

Saragih, Amrin and S. Anggraini Thesesia. 2014. Course Book Writing. Medan: UNIMED Press.

Sudharma, Putra. "The Effect of Screencast-O-Matic on Students' Speaking Ability of Descriptive Text", A Thesis, UIN Syarif Hidayatullah Jakarta, 2017 